\title{
Intestinal immunoglobulins in children with coeliac disease
}

\author{
E. SAVILAHTI \\ From the Children's Hospital, University of Helsinki, Finland
}

SUMMARY The numbers of immunoglobulin-containing cells in jejunal biopsy specimens of 19 children with active coeliac disease aged 0.5 to 16.5 years were studied by direct immunofluorescence. Intestinal juice immunoglobulins were measured in 14 of these patients.

The number of IgA-containing cells was twice and the number of $\operatorname{IgM}$-containing cells 2.5 times that of age-matched controls. There were also more IgG-, IgE-, and IgD-containing cells in the jejunal mucosa of the coeliac patients, but the absolute numbers of these cells were low. The immunoglobulin content of the intestinal juice was not altered in coeliacs.

A follow-up biopsy specimen was available from seven patients kept on a strict gluten-free diet for one to four months. A significant fall in the numbers of immunoglobulin-containing cells was seen, and they did not differ at that time from the controls. Two patients were followed until full normalization of the jejunal structure and they had normal numbers of immunoglobulin-containing cells.

In children with coeliac disease in contrast to adult coeliacs, the study shows that the IgA-producing system is quantitatively stimulated during gluten challenge. The rapid drop in the numbers of immunoglobulin-containing cells after gluten withdrawal suggests that there is no quantitative abnormality in the local immunoglobulin-producing system of the gut in coeliac disease.

Recently, interest has been focused on the local immunoglobulin-producing system of the gut. The distribution of immunoglobulin-containing cells in the mucosa of the gastrointestinal tract of normai persons is well established (Crabbé, Carbonara, and Heremans, 1965; Crabbé and Heremans, 1966), and the changes taking place in this system have been investigated from early infancy (Crabbé, 1967; Savilahti, 1972a). These cells have also been studied in various gastrointestinal diseases (Odgers and Wangel, 1968; Söltoft, 1969), especially in coeliac disease. Rubin, Fauci, Sleisenger, and Jefferies (1965) did not observe any difference between immunoglobulincontaining cells of adult coeliacs and controls. Excess of IgM-containing cells was noted by Söltoft (1970), Douglas, Crabbé, and Hobbs (1970), and Pettingale (1971), and in the two latter studies reduction in the numbers of IgA-containing cells was also found in the jejunal mucosa of adult coeliac patients. In contrast, in children with coeliac

Address for reprints: Children's Hospital, Stenbäckinkatu 11, 00290 Helsinki 29, Finland

Received for publication 4 October, 1972. disease both IgA- and IgM-containing cells were found to be present in the jejunal mucosa in increased numbers (Jos, 1972).

This study concerns children of all ages with active coeliac disease. The numbers of immunoglobulin-containing cells in the jejunal biopsy specimens, and the concentration of immunoglobulins in the intestinal juice and serum were measured, and correlations between these parameters obtained were sought as well as the different age groups compared. A follow-up study was performed on some of the patients after a period of a strict gluten-free diet.

\section{Patients}

The subjects of this study were 19 children, for whom intestinal biopsies were available either before any dietary treatment (17 patients) or during relapse. All had typical symptoms of coeliac disease, total villous atrophy of the jejunum, and a favourable clinical response to a gluten-free diet. The patients were aged between 0.5 to 16.5 years and six of them 
were under the age of 2 . In seven patients a control biopsy specimen was studied after a gluten-free diet for one to four months. Five of these stayed in hospital during the whole interval to the follow-up biopsy. In all seven biopsies total villous atrophy was still found, but the epithelial cell height had become normal by the time of the second biopsy. Two cases were followed until the intestinal structure had become normal. Nineteen age-matched controls without intestinal diseases were selected from a larger group of children, the more detailed data of whom have been presented earlier (Savilahti, 1972a).

\section{Methods}

\section{BIOPSY SPECIMENS}

Jejunal biopsies were taken from the upper part of the jejunum with a Crosby-Kugler biopsy capsule, paediatric size. They were divided when fresh. One part was used for ordinary histological studies and graded as described elsewhere (Kuitunen, 1966). The other part was processed for direct immunofluorescent study as described earlier (Savilahti, 1972a).

\section{FLUORESCENT MICROSCOPY}

The microscope used was a Leitz Ortholux, with cardioid dark-field condensors and a HB 200 mercury vapour lamp as light source. The best distinction between autofluorescent and stained cells was achieved with UG 5, $1 \mathrm{~mm}$, and BG 12, $1 \mathrm{~mm}$, excitation filters in succession and a $\mathrm{K} 460$ blocking filter. This combination was also used for colour photography on Kodak Ectachrome daylight films. For black-and-white photography on Kodak Tri X films a BG $12,5 \mathrm{~mm}$, primary filter and a K 530 blocking filter were used.

Fluorescent cells were counted directly on stained slides at $\times 1000$ magnification in an area of at least $0.2 \mathrm{~mm}^{2}$ between the epithelium and muscularis mucosae. By this method the area occupied by Lieberkühn's crypts was included. In eight cases the proportion of the lamina propria occupied by IgA- and IgM-containing cells was determined from colour slides by point counting (Weibel and Elias, 1967), as described earlier (Savilahti, 1972a).

All biopsy specimens were studied with anti-IgA, -IgM, and -IgG serum. In 13 of the primary biopsies the number of IgE-containing cells was measured and five specimens were studied with anti-IgD serum.

\section{IMMUNOGLOBULIN MEASUREMENT}

Intestinal juice was collected from the lower part of the duodenum via the biopsy tubing into a flask kept in ice. Immunoglobulins were measured by electroimmunodiffusion (Lopez, Tsu, and Hyslop, 1969). Immunoglobulins of the serum samples taken at the time of biopsy were measured by the single radial immunodiffusion method (Mancini, Carbonara, and Heremans, 1965) as modified by Immonen (1967). The results were expressed as percentages of values for normal children (Immonen, 1967) for use in statistical analysis.

\section{ANTISERA}

For immunoglobulin measurements rabbit antihuman $\operatorname{IgA}$, IgM, and IgC were prepared in our own laboratory (Savilahti, 1972a). For staining of tissue sections commercial goat antisera to human IgA, IgM, and IgG labelled with fluorescein isothiocynate (Hyland Lab., Inc., California, U.S.A.) were employed. Sheep antiserum to human IgE (Pharmacia, Sweden) and rabbit antiserum to IgD (Behringwerke, Germany) were conjugated with fluorescein by the method of Linder and Tallberg (1970). The monospecificity, lack of cross reactivity, and $F / P$ ratios of the antisera were studied as described earlier (Savilahti, 1972a). The F/P ratio of the anti-IgD serum was $2 \cdot 8$.

\section{STATISTICAL ANALYSES}

Mean values, standard deviation, $t$ values between the groups compared, and correlation coefficients between the various parameters measured were calculated with a Hewlett-Packard 9100 B calculator according to its standard programs.

\section{Results}

IMMUNOGLOBULIN-CONTAINING CELLS OF THE BIOPSY SPECIMENS

The number of IgA-containing cells was increased in every patient compared with the mean of the controls. On average twice as many IgA-containing cells were seen in biopsies of coeliacs as in those of controls (Fig. 1). The difference between the groups is statistically highly significant $(\mathrm{P}<0.001)$. There was no difference in cell numbers in coeliacs under 2 years of age and the older patients (Fig. 1). Although the area occupied by IgA-containing cells was not proportionally increased (Fig. 2), in all eight patients studied it was greater than the mean of the control group. The majority of fluorescent cells were oval with eccentric nuclei and slightly granular cytoplasm, suggesting that they were plasma cells. The number of positively stained round cells with only a rim of fluorescence aroung the nucleus was relatively greater in the patients than in the controls. Most cells were located beneath the surface epithelium. The anti-IgA serum stained the basement membranes of the surface epithelium and the crypts 


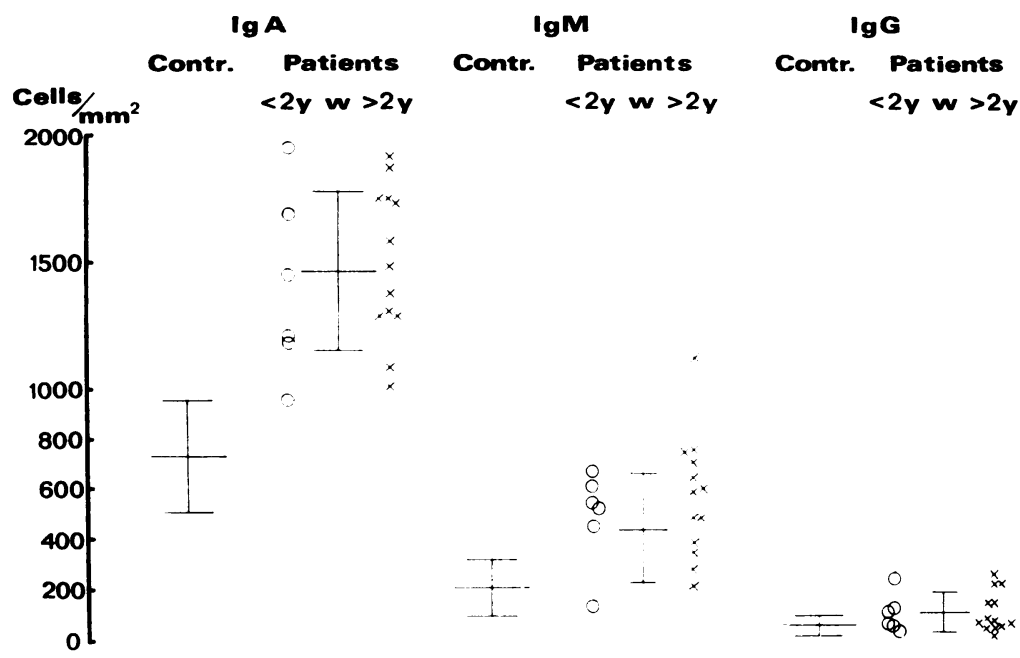

Fig. 1 Immunoglobulincontaining cells in the jejunal mucosa of patients and controls (cells $/ \mathrm{mm}^{2}$ ). The mean values $\pm S D$ are indicated for the controls and for the whole group of patients $(W) . \bigcirc=$ patient under 2 years of age, $\times=$ patient over 2 years of age. intensely, and the fluorescence was clear in the intercellular spaces was well as in the apical parts of the surface epithelial cells (Fig. 3).

In all but one specimen the number of IgM-containing cells was above the mean of the control group. The average increase was 2.5 times that of the controls (Fig. 1), but the scatter of the numbers of IgM-containing cells was relatively wider than that of IgA-containing cells. The difference between patients and controls is highly significant $(P<0.001)$. Cell densities in patients under 2 years of age did not differ from those of the older ones (Fig. 1). Like the cells with IgA, the IgM-containing cells also occupied a smaller proportion of the lamina propria than would have been expected from their increased number (Fig. 4), but in every specimen studied the area was larger than the mean of the controls. The morphology and location of the IgM-containing cells was similar to that observed with anti-IgA serum. Slight staining of the basement membranes of the epithelial cells of the surface and crypts was seen, as well as staining of the spaces between the epithelial cells.

The number of IgG-containing cells was also

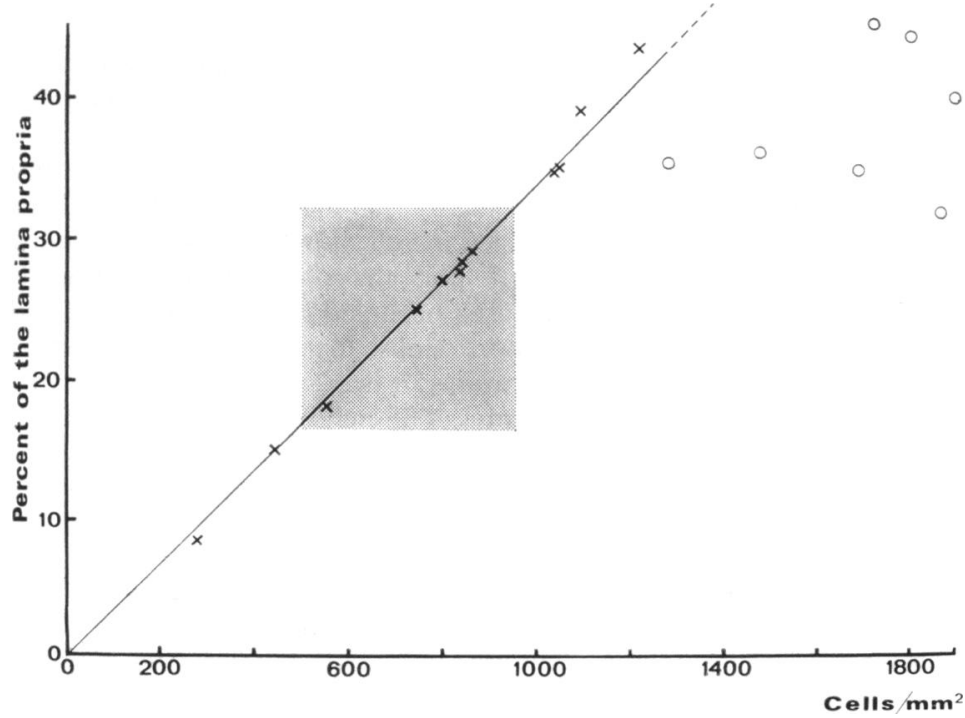

Fig. 2 Relationship between the proportion of the lamina propria occupied by IgAcontaining cells and their number per $\mathrm{mm}^{2}$. correlation between percentages and cell numbers in normal intestine, - - imaginary extrapolation of the correlation in morphologically normal intestine. $\times=$ case without intestinal diseases, $\mathrm{O}=$ patient with coeliac disease. Shaded area $=$ mean of the control group $\pm S D$. 


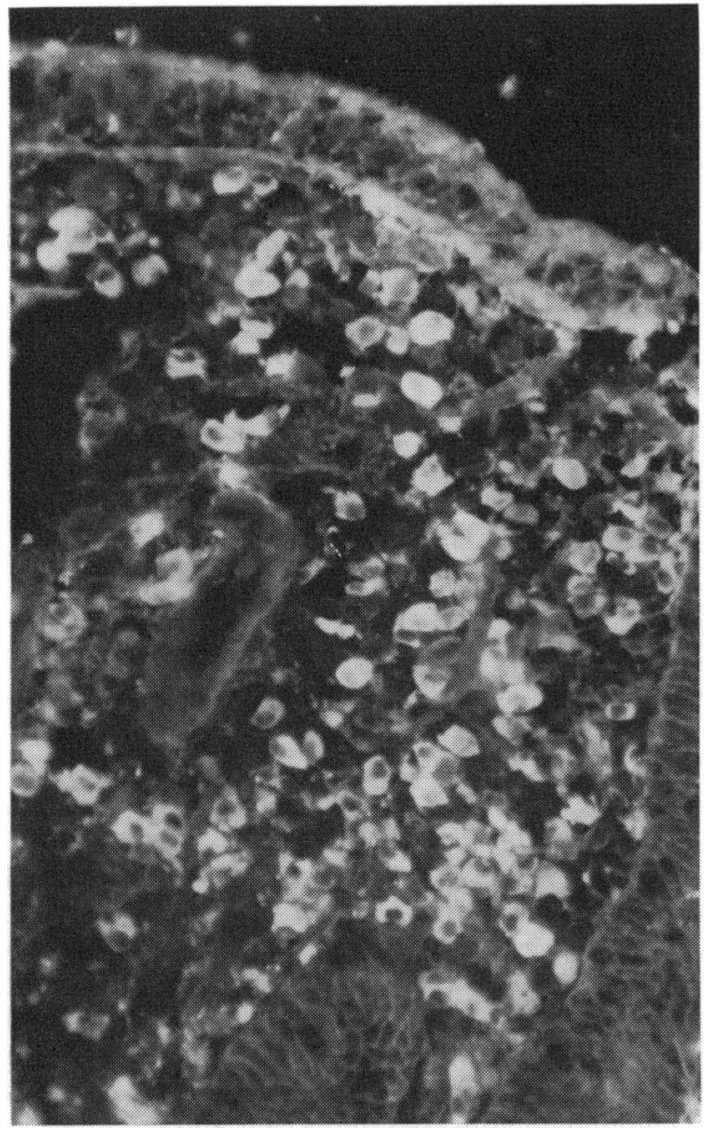

increased (Fig. 1). The difference between patients and controls is significant $(P<0.01)$. In one of the patients no IgE-containing cells were seen $\left(<3 / \mathrm{mm}^{2}\right)$ and in 12 others their number varied from 3 to 184 cells $/ \mathrm{mm}^{2}$ (mean 49 cells $/ \mathrm{mm}^{2}$ ). In two of the six controls no fluorescent cells were seen with anti-IgE serum $\left(<2\right.$ cells $\left./ \mathrm{mm}^{2}\right)$ and in the rest their number was between 3 and 16 cells $/ \mathrm{mm}^{2}$. Cells containing IgD were also more abundant in five patients studied (mean 33 cells $/ \mathrm{mm}^{2}$ ) than in seven controls (mean 16 cells $/ \mathrm{mm}^{2}$ ).

A follow-up biopsy specimen was available in seven cases after a short period on a gluten-free diet (one to four months). There was a significant fall in the numbers of cells containing $\operatorname{IgA}(P<0.02)$ and $\operatorname{IgM}(\mathrm{P}<0.05)$ compared with the numbers seen in the primary biopsy (Fig. 5), and at the time of the second biopsy the counts did not differ significantly from the controls. The number of IgG-containing cells had also fallen so that the average did not differ from that of the controls.

IMMUNOGLOBULINS IN THE INTESTINAL JUICE

The concentrations of $\operatorname{IgA}$ and IgM did not differ significantly in patients and controls. The mean

Fig. 3 Jejunal mucosa stained with anti-IgA serum. In addition to intracellular staining, the basement membranes, interepithelial spaces and apical parts of surface epithelial cells show positive fluorescence. $(\times 500)$.

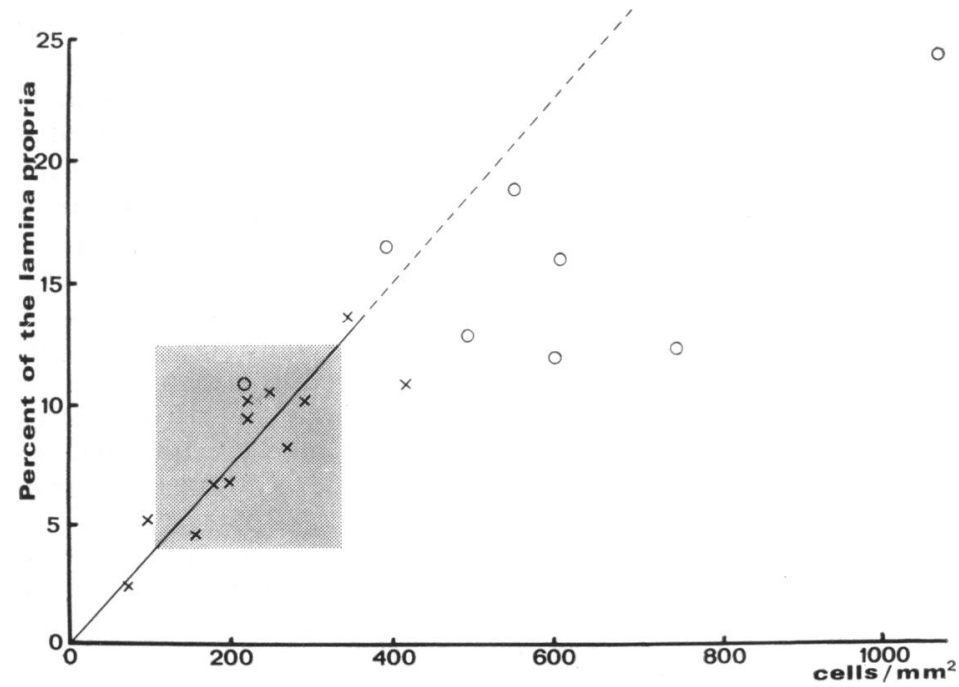

Fig. 4 Relationship between the proportion of the lamina propria occupied by IgM-containing cells and their number per $\mathrm{mm}^{2}$. Symbols as in Figure 2. 


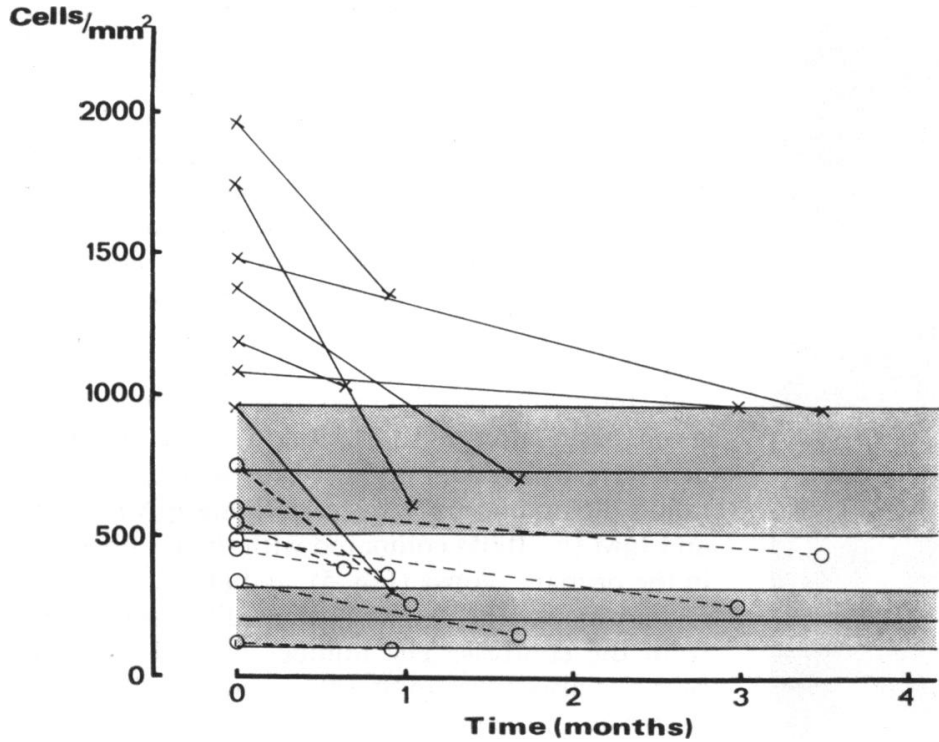

values for these immunoglobulins were somewhat higher in the coeliac patients, but also varied more (Table I). In only three patients were the IgG concentrations above $0.9 \mathrm{mg} / 100 \mathrm{ml}$, and one control had detectable IgG in the intestinal juice.

\begin{tabular}{|c|c|c|}
\hline \multirow[t]{3}{*}{ Immunoglobulin } & \multicolumn{2}{|c|}{ Total No. Studied } \\
\hline & \multirow{2}{*}{$\frac{\text { Patients }}{14}$} & \multirow{2}{*}{$\frac{\text { Controls }}{18}$} \\
\hline & & \\
\hline $\begin{array}{l}\operatorname{lgA}(\mathrm{mg} / 100 \mathrm{ml}) \\
\text { Number of subjects } \\
\text { with values below } 0.5^{1}\end{array}$ & $\mathbf{0}$ & 0 \\
\hline $\begin{array}{l}\text { Mean concentration } \pm S D \\
\text { Observed range of values }\end{array}$ & $\begin{array}{l}3 \cdot 9 \pm 2 \cdot 5 \\
0 \cdot 7 \cdot 10 \cdot 2\end{array}$ & $\begin{array}{l}3 \cdot 5 \pm 1 \cdot 4 \\
1 \cdot 7-6 \cdot 0\end{array}$ \\
\hline \multicolumn{3}{|l|}{$\lg M(\mathrm{mg} / 100 \mathrm{ml})$} \\
\hline $\begin{array}{l}\text { Number of subjects with } \\
\text { values below } 0 \cdot 1^{1}\end{array}$ & $5^{2}$ & 2 \\
\hline $\begin{array}{l}\text { Mean concentration } \pm S D \\
\text { Observed range of values }\end{array}$ & $\begin{array}{l}3 \cdot 1 \pm 5 \cdot 1 \\
0-18 \cdot 0\end{array}$ & $\begin{array}{l}2 \cdot 1 \pm 1 \cdot 8 \\
0-6 \cdot 5\end{array}$ \\
\hline
\end{tabular}

Table I Immunoglobulins in the intestinal juice

'Sensitivity of the measurement.

'Values for IgM, that were below the limit of detectability were extrapolated from the plot of the cumulative frequency of samples against the IgM level on distribution paper.

No positive correlations were found between the concentrations of IgA and IgM in the intestinal juice and the numbers of cells containing $\operatorname{IgA}$ and IgM.

SERUM IMMUNOGLOBULINS

In 15 of the patients serum IgA was above the mean
Fig. 5 Follow-up results in seven patients treated with a gluten-free diet. $\times=I g A$-containing cells of a patients, $\bigcirc=$ IgM-containing cells. Shaded areas $=$ means of the control group $\pm S D$ for Ig $A$-(upper) and IgM-containing (lower) cells. for age; on the average it was $204 \%$ for age. IgM was on the average $114 \%$ for age, and IgG $103 \%$. In the seven cases followed the initial IgA concentration was $210 \%$ for age and fell to the average of $103 \%$ by the time of the follow-up biopsy. IgM and IgG values remained essentially unchanged. No positive correlation was found between the numbers of immunoglobulin-containing cells and serum levels of immunoglobulins.

\section{Discussion}

A marked increase in the numbers of IgA- and IgMcontaining cells in the small intestinal mucosa of children with active coeliac disease was found in this study. It is also obvious that the area occupied by these cells was relatively increased in the children with coeliac disease. The number of cells containing IgG was also elevated, but on the average comprised less than $1 / 20$ of the total number of immunoglobulin-containing cells in the jejunal mucosa of coeliac patients. Likewise, more IgE- and IgDcontaining cells were seen in patients than in controls, yet their absolute number was low. It is therefore unlikely that antibodies of the IgG, IgE, and IgD types play any important role locally or intramucosally in coeliac disease.

Direct cell counts of biopsy specimens were used in this study to measure the numbers of immunoglobulin-containing cells. In earlier studies (Crabbé et al, 1965; Söltoft, 1970; Douglas et al, 1970; Pettingale, 1971) planimetric methods have been 
used to measure the proportion of the lamina propria occupied by fluorescent cells. This leads to underestimation of the total quantity of immunoglobulin-containing cells; as the volume of the lamina propria is greatly increased in the jejunal mucosa with villous atrophy (Kuitunen, 1966; Douglas et al, 1970) compared with the healthy tissue. Moreover, the average cell size of the immunoglobulincontaining cells is smaller in coeliacs than in persons with normal intestinal structure, as reported by Pettingale (1971) and confirmed in the present study. When the planimetric method is used and a direct cell count is also made on the same biopsy specimens, as was done in some of the cases in this study, it is obvious that, for the reasons mentioned above, the absolute numbers of IgA- and IgMcontaining cells are more increased than the proportion of the lamina propria occupied by them. For the same reasons, in my opinion direct cell counts of the mucosal specimens better reflect the total cell mass containing immunoglobulins and presumably also the activity of the intestinal mucosa in producing immunoglobulins.

The finding of increased numbers of $\operatorname{IgA-con-}$ taining cells is in accord with the report of Jos (1972), who also studied children with coeliac disease. In studies on adult patients, the proportion of these cells is found to be either unchanged (Rubin et al, 1965; Söltoft, 1970) or slightly reduced (Douglas et al, 1970), while Pettingale (1971), who studied elderly patients, observed significantly lower densities of these cells than in controls. It might be speculated that the discrepancy in various reports is due to the differences in the ages of the patients studied. It is likely that adult coeliac patients have had the disease in clinically silent form for decades, and this could lead to exhaustion of the local $\lg \mathrm{A}$ producing system of the gut when continuously stimulated by gluten challenge. No such tendency towards a decrease in the numbers of these cells with age was shown by the present series of children, a result which is in agreement with studies of jejunal biopsies in vitro. Loeb, Strober, Falchuk, and Laster (1971) and Falchuk and Strober (1972) observed increased synthesis of $\operatorname{IgA}$ in biopsy specimens of coeliac patients after gluten challenge, irrespective of the ages of the patients.

The increased numbers of IgM-containing cells found in this study confirm earlier findings made in adults (Söltoft, 1970; Douglas et al, 1970; Pettingale, 1971) as well as in children (Jos, 1972) with coeliac disease and in in-vitro studies of biopsy specimens from coeliac patients (Loeb et al, 1971; Falchuk and Strober, 1972). The increase in the number of IgMcontaining cells is obviously not specific for coeliac disease as a similar elevation of these cells is found in the malabsorption syndrome induced by cow's milk (Savilahti, 1972b; Jos, 1972).

Reports on the numbers of immunoglobulincontaining cells in biopsy specimens of adult coeliacs treated with a gluten-free diet are conflicting. Söltoft (1970) did not notice any difference between treated and untreated patients, while reduction of the density of IgA-containing cells was noted by Douglas et al (1970) in two treated patients with normal villous structure of the jejunum. A normal number of immunoglobulin-containing cells was seen in one patient with normalized jejunal mucosa studied by Pettingale (1971). Differences in results are probably due to dietary factors, as a strict gluten-free diet is difficult to achieve. Because in this study most patients were followed up in hospital and in every patient a favourable morphological response was noted in the intestinal mucosa, it can be assumed that avoidance of gluten had been complete. In these cases there was a rapid fall in the numbers of IgA-, IgM-, and IgG-containing cells and they were within the normal range after a short period on a glutenfree diet and remained so in two patients followed up until the intestinal mucosa was entirely normal.

In contrast to Douglas et al (1970), I found no increase in intestinal juice IgM in coeliac children and the IgA values were also normal. However, total secretion of the immunoglobulins may be increased, as these are secreted into a larger volume of intestinal fluid in coeliacs.

The serum concentrations of IgA were raised in this group of patients, as has been observed earlier in children with coeliac disease (Immonem, Kouvalainen, and Visakorpi, 1966). No direct correlation was observed between the serum levels and the numbers of IgA-containing cells in the jejunal mucosa. Nevertheless the fact that treatment led to a simultaneous fall in both parameters favours the view that increased numbers of IgA-containing cells in the jejunal mucosa are the source of this rise. In coeliac patients, as in patients with IgA deficiency (Savilahti, 1973), the increase in the numbers of IgM-containing cells was not reflected in the serum IgM level, a finding which does not accord with the conclusion of Pettingale (1971), who reported a correlation between IgM cell densities and the serum level of $\mathrm{IgM}$.

This study verifies earlier findings (Söltoft, 1970; Douglas et al, 1970; Pettingale, 1971; Jos, 1972) that there are clear changes in the immunoglobulincontaining cells in the intestinal mucosa in active coeliac disease. However, in children the numbers of IgA-containing cells are greatly increased, while in adults they have been found to be normal or decreased (Rubin et al, 1965; Söltoft, 1970; Douglas, et al, 1970; Pettingale, 1972). This finding indicates 
that in the early phase of coeliac disease the IgAproducing system of the gut is stimulated. The rapid normalization of the numbers of immunoglobulincontaining cells suggests that there is no quantitative abnormality in the local immunologlobulinproducing system of the gut in coeliac disease.

This work has been supported by grants from the Sigrid Jusélius Foundation and the National Research Council for Medical Sciences, Finland.

\section{References}

Crabbé, P. A. (1967). Signification du Tissu Lymphoide des Muqueuses Digestives, p. 204. Arscia, Brussels.

Crabbe, P. A., Carbonara, A. O., and Heremans, J. F. (1965). The normal human intestinal mucosa as a major source of plasma cells containing $\gamma$ A-immunoglobulin. Lab. Invest., 14, 235248.

Crabbe, P. A., and Heremans, J. F. (1966). The distribution of immunoglobulin-containing cells along the human gastrointestinal tract. Gastroenterology, 51, 305-316.

Douglas, A. P., Crabbé, P. A., and Hobbs, J. R. (1970). Immunochemical studies of the serum, intestinal secretions and intestinal mucosa in patients with adult celiac disease and other forms of the celiac syndrome. Gastroenterology, 59, 414-425.

Falchuk, Z. M., and Strober, W. (1972). Increased jejunal immunoglobulin synthesis in patients with nontropical sprue as measured by a solid phase immunoadsorption technique.J. Lab. clin. Med., 79, 1004-1013.

Immonen, P. (1967). Levels of the serum immunoglobulins $\gamma$ A, $\gamma \mathbf{G}$ and $\gamma \mathrm{M}$ in the malabsorption syndrome in children. Ann. Paediat. Fenn., 13, 115-153.

Immonen, P., Kouvalainen, K., and Visakorpi, J. K. (1966). The immunoelectrophoretic gamma-A globulin in malabsorption. Ann. Paediat. (Basel), 207, 269-276.

Jos, J. (1972). Immunohistochimie de la muqueuse intestinale dans les syndromes de malabsorption de l'enfant. (Abstr.). Arch. Mal. Appar. dig., 61, 368C.
Kuitunen, P. (1966). Duodenal-jejunal histology in malabsorption syndrome in infants. Ann. Paediat. Fenn., 12, 101-132.

Linder, E., and Tallberg, T. (1970). Preparation of anti-IgG conjugates for immunofluorescence using immunoadsorbents for purification. Ann. Med. exp. Fenn., 48, 212-220.

Loeb, P. M., Strober, W., Falchuk, Z. M., and Laster, L. (1971) Incorporation of L-leusine-1 ${ }^{14} \mathrm{C}$ into immunoglobulins by jejunal biopsies of patients with celiac sprue and other gastrointestinal diseases. J. clin. Invest., 50, 559-569.

Lopez, M., Tsu, T., and Hyslop, N. E., Jr. (1969). Studies of electroimmunodiffusion: Immunochemical quantitation of proteins in dilute solutions. Immunochemistry, 6, 513-526.

Mancini, G., Carbonara, A. O., and Heremans, J. F. (1965). Immunochemical quantitation of antigens by single radial immunodiffusion. Int. J. Immunochem., 2, 235-254.

Odgers, R. J., and Wangel, A. G. (1968). Abnormalities in IgAcontaining mononuclear cells in the gastric lesion of pernicious anaemia. Lancet, 2, 846-849.

Pettingale, K. W. (1971). Immunoglobulin-containing cells in the coeliac syndrome. Gut, 12, 291-296.

Rubin, W., Fauci, A. S., Sleisenger, M. H., and Jefferies, G. H. (1965). Immunofluorescent studies in adult celiac disease. $J$. clin. Invest., 44, 475-485.

Savilahti, E. (1973). Immunoglobulin-containing cells in the intestinal mucosa and immunoglobulins in the intestinal juice in children. Clin. exp. Immunol., 11, 415-425.

Savilahti, E. (1972b). Local immunological reaction in the small intestinal mucosa in children with the malabsorption syndrome induced by cow's milk. Acta paediat. scand., 61, 238.

Savilahti, E. (1972c). IgA deficiency in children. Immunoglobulincontaining cells in the intestinal mucosa, immunoglobulins in secretions and serum IgA levels. Clin. exp. Immunol., in the press.

Söltoft, J. (1969). Immunoglobulin-containing cells in jejunal mucosa and in ulcerative colitis and regional enteritis. Scand. $J$. Gastroenterol., 4, 353-360.

Söltoft, J. (1970). Immunoglobulin-containing cells in non-tropical sprue. Clin. exp. Immunol., 6, 413-420.

Weibel, E. R., and Elias, H. (1967). Introduction to stereologic principles. In Quantitutive Methods in Morphology (Symposium, Wiesbaden, 1965), Edited by E. R. Weibel, and H. Elias, pp. 89-98. Springer, Berlin. 